\section{Employment exclusion in Spain: a territorial approach}

\section{Employment exclusion in Spain}

\author{
Matilde Lafuente-Lechuga, Ursula Faura-Martínez and \\ Olga García-Luque \\ Universidad de Murcia, Facultad de Economía y Empresa, Murcia, Spain
}

Received 2 April 2018 Revised 21 December 2018 Accepted 13 February 2019

\begin{abstract}
Purpose - This paper studies social inequality in the vital field of employment in Spain during the crisis period 2009-2014.

Design/methodology/approach - Factor analysis is used to build a synthetic index of employment exclusion. The starting information matrix collects data from a wide set of employment variables for all 17 Spanish autonomous communities and the autonomous cities of Ceuta and Melilla. Based on this information, four factors are extracted which explain employment exclusion in different situations of vulnerability, such as unemployment, temporality, poverty or low pay.

Findings - In the territorial ranking, Madrid, Basque Country, Aragon and Catalonia show the lowest risk of employment exclusion, whereas Ceuta, Andalusia, Extremadura and Canary Islands show the highest ones. Originality/value - The main value of this research is that it confirms the need for coordination of public policies in order to foster social and territorial cohesion in Spain.
\end{abstract}

Keywords Employment exclusion index, Factor analysis, Regional classification, Economic crisis

Paper type Research paper

\section{Introduction}

The employment dimension has been proven paramount in social exclusion analysis. This study aims at broadening the knowledge on the factors shaping the risk of exclusion in the employment dimension. To this end, data were collected from a large number of workrelated variables so as to define a synthetic indicator of employment exclusion revealing the territorial gap in Spain and the factors accounting for such disparities.

Several structural changes related to the labour market, the complexity and fragmentation of the social structure and the regression in the protection of citizen rights by public administrations are put forward when explaining the increase in social inequalities and vulnerable population groups, referred to by the term social exclusion [Laparra Navarro et al. (2007); Ayala Cañón (2008); Hernández Pedreño (2008)]. This process has been exacerbated by the crisis, expanding the risk of social exclusion to new population groups [Fundación FOESSA (2014); Hernández Pedreño (2014); Leahy et al. (2015)] and widening the regional gap.

Spain's economic revival is not making up lost ground in terms of economic and social welfare. In fact, Spain has one of the highest percentages of economically vulnerable

(C) Matilde Lafuente-Lechuga, Ursula Faura-Martínez and Olga García-Luque. Published in Applied Economic Analysis. Published by Emerald Publishing Limited. This article is published under the Creative Commons Attribution (CC BY 4.0) licence. Anyone may reproduce, distribute, translate and create derivative works of this article (for both commercial and non-commercial purposes), subject to full attribution to the original publication and authors. The full terms of this licence may be seen at http://creativecommons.org/licences/by/4.0/legalcode

JEL classification - I31, I38, J81

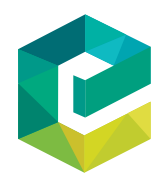

Applied Economic Analysis Vol. 27 No. 80, 2019 pp. $127-149$

Emerald Publishing Limited 2632-279X DOI 10.1108/AEA-06-2019-0001 
population in the European Union [Ayala Cañón et al. (2018), p. 19], which implies great opportunity costs in relation to lost private and public income, deterioration of human capital, increasing unease or the reduction of intergenerational social mobility [OECD (2017)].

It is necessary to underline that social exclusion is a structural, dynamic, multifactorial and multidimensional phenomenon because the exclusion factors are a combination of interconnected circumstances that have an impact on different life spheres [European Commission (2003), Bradshaw et al. (2004); Levitas et al. (2007)]. Among these, the employment area stands out due to its connection with the other dimensions of social exclusion (income, education, health, housing, social relationships or participation). Unemployment, temporary work, low work intensity or low pay jeopardise the level and stability of household income, which may be exposed to situations of poverty or material deprivation, which in turn may lead to new problems related to health, home maintenance and family relationships; this is an accumulation of disadvantages that are typical of social exclusion processes.

Two decades ago, Atkinson (1998) made two assertions. First, the costs of unemployment for the people who lose their jobs go beyond the lost income, and second, having a job is not equal to social inclusion. In this vein, although the quantity of jobs is still a crucial issue, increasing attention is currently being paid to aspects related to job quality, as it is a determining factor in the welfare of people and their households, having a positive impact on productivity and social cohesion [Cazes et al. (2015)].

This shift in perspective is observed in the direction of the European Employment Strategy. Initially aimed at fighting unemployment, the goals of the European Employment Strategy have been addressed to the promotion of the employment rate and quality jobs and the increase in human capital, following the priorities established in the current Europe 2020 Strategy [European Commission (2010)]. The EU's social dimension has been strengthened by the European Pillar of Social Rights and the European Labour Authority [European Commission (2018a)], which foster equal opportunities in the labour market and fair working conditions. This is an explicit attempt to decrease social inequalities broadly derived from the employment sphere.

Consequently, it is crucial to research in depth into the determinants and measurement of social exclusion, and employment exclusion in particular, to design public policies aimed at guaranteeing inclusive growth and equal opportunities.

This paper analyses social inequality in the employment dimension as a multiattribute decision problem in every Spanish territory with autonomous government, that is, seventeen communities and two autonomous cities, during the crisis (2009-2014) by conducting factor analysis. Four factors related to precarious situations that account for employment exclusion have been extracted. This analysis aims at establishing a statistical criterion to classify autonomous communities and cities and obtain a final ranking.

The next section gives a brief review of the literature on employment exclusion, featuring the socioeconomic context in which its conceptualization is developed and the different approaches taken for measuring it. In the third section, the methodology is presented, together with the transformation carried out to construct the synthetic employment exclusion indicator. The fourth section begins by examining the results and then the factors shaping the risk of employment exclusion in terms of spatial and temporal evolution. The employment exclusion ranking by regions, obtained by the synthetic indicator, is also presented, and the main conclusions are drawn in the last section. 


\section{Context and background}

The relevance of work as a source of social integration has been widely investigated in social sciences [Castel (1995), Atkinson (1998); Levitas et al. (2007)]. In fact, work has been regarded as one of the two axes of exclusion/inclusion in developed societies, together with family and social relationships [Castel (1995); Subirats (2005)]. In keeping with this, Kalleberg (2009, p. 1) noticed that "work is a core activity in society. It is central to individual identity, links individuals to each other, and locates people within the stratification system".

Since the late 1970s, labour flexibility has put an end to stable employment and brought about the increase of precarious work. These key factors in the social dualisation arose from labour segmentation [Gordon et al. (1982), Davidsson and Naczyk (2009)]. Therefore, a distinction is usually made between typical or standard employment (full-time, permanent work for a single employer) and atypical or non-standard employment, which is an umbrella term for different employment arrangements, such as temporary employment, part-time work, temporary agency work or subcontracted labour, and dependent self-employment [ILO (2016), pp. 7-9]. Although the institutional elements of the labour market (employment protection legislation, minimum wage or unions, among others) are at the heart of the debate, the vast amount of literature on the subject has not yet drawn clear conclusions on their impact in terms of efficiency and equity [Betcherman (2012)].

The potential of work as an integrating element has been weakened in the last decade due to the economic crisis [Eurofound (2013); Manzanera Román et al. (2016)] and technological change and the new forms of employment associated with the digital economy [Broughton et al. (2016); European Commission (2018b)].

European countries have responded to increasing unemployment with austerity policies and reforms aimed at making the labour market more flexible, which has extended and diversified precarious employment [Lang et al. (2013); Lorente Campos and Guamán Hernández (2018)]. In consequence, the EU as a whole, and Spain in particular, has reached high levels of labour and economic instability and insecurity, inflicting negative effects on citizens (state of health, professional development, social relationships or maintenance of the home], economic growth and social cohesion [Benach et al. (2014), Frazer et al. (2014); Eurofound (2017), Arundel and Lennartz (2018)]. Despite the recovery of the labour market, these issues continue to exist [European Commission (2018b)].

On the other hand, the digital economy promotes new tasks and forms of work on the fringes of labour legislation, such as crowdwork and work on demand via apps. Likewise, automation and technological change raise the question of the disappearance of a good proportion of jobs in the near future, increasing the job polarisation between low- and highskilled workers and raising spatial inequality caused by the adjustment process [ILO (2017), pp. 24-26].

Therefore, employment exclusion does not only refer to the most traditional aspect (related to unemployment and difficult access to labour market for some groups, such as the young, women, people with disabilities, immigrants or ethnic minorities) in this context, but also to a wide range of situations of socioeconomic precariousness and vulnerability related to employment. According to Standing (2011), this is the precariat, a new social class.

There is a vast amount of literature on employment from both micro- and macroperspectives. This study takes the latter with two possible approaches in the international and interregional comparative study when tackling the problems derived from participation/exclusion in the labour market.

The first approach analyses the comparative results focusing on either one variable of interest or several variables separately, among which the most frequent are employment, unemployment, income or, more recently, the transitions in labour market status [Ward-
Employment exclusion in Spain 
Warmedinger and Macchiarelli (2013), Fulvimari et al. (2016)]. The links between employment situation and poverty or social exclusion have been increasingly present in this type of research, which has put forward new analysis perspectives. For instance, alternative ratios have been used to measure other forms of labour underutilisation when the unemployment rate is deemed insufficient [ILO (2018)]; it has also been suggested to adjust employment rate to work intensity [Brandolini and Viviano (2017)], or to implement welfare measures through a household employment deprivation index [Gradín et al. (2017)]. On the other hand, Felgueroso et al. (2017) built an indicator to account for the most vulnerable population with regard to employment, providing information for every autonomous community in Spain (EVAE rate).

When employment is regarded as one of the dimensions of social exclusion/inclusion, the second approach considers different methods for multidimensional measurement of social exclusion, or alternatively of welfare or quality of life, because "quality of life is the background concern of much of the work on social exclusion" [Levitas et al. (2007), p. 24].

The EU's multidimensional social exclusion indicator (AROPE rate) includes the employment dimension through the measurement of the population living in (quasi-)jobless households, reporting on the low or null participation in the labour market[1]. Nevertheless, the risk of poverty or social exclusion does not only affect those with weak links with the labour market but it has also extended to full-time workers [Eurostat (2018), p. 114], the socalled working poverty[2]. Additionally, there are a wide range of indicators available that are part of the portfolio of EU social indicators [European Commission (2015)].

Furthermore, the EU has developed a set of indicators of quality of life that concern the analysis of nine dimensions based on expert recommendations [Eurostat (2017)]. The employment dimension, Productive or main activity, relates to both quantity aspects (employment, unemployment and underemployment) and qualitative ones (income and benefits from employment, health and safety at work, work/life balance, temporary work and assessment of job quality), in the cases of both paid and unpaid work, although the variables available for the latter are scarce.

A few comparative analyses of the quality of life at work across European regions have been conducted, mainly using OECD's measurements (2014a). However, territorial breakdown usually involves fewer indicators available [OECD (2018)]. On the other hand, the analysis of life quality from a regional perspective may vary from the national one, as proposed by Lagas et al. (2015) when building their regional quality of living index, where youth and adult unemployment rates are included as indicators of Purchasing power and employment dimension.

In Spain, Fundación FOESSA elaborated the Synthetic Index of Social Exclusion by mining their own survey which includes employment indicators which are not available in official statistics, such as marginal activities (cardboard collecting, leafleting or begging) and irregular employment or employment without contract [Laparra Navarro et al. (2014)]. With regard to life quality, the National Statistics Institute [INE] provides a reduced version of Eurostat's European indicators, which especially affects the variables related to employment quality [INE (2018a)]. Additionally, INE has recently started to aggregate the information into a global index of quality of life, displaying results by autonomous communities and dimensions, such us employment, among others. Furthermore, Merino Llorente et al. (2012) develop a Synthetic Indicator of Dynamic Work Quality for the Spanish autonomies. This indicator incorporates four dimensions (employment conditions, job conditions, labour relations and social policies), observing the regional convergency/ divergency in terms of quality levels in employment between 2000 and 2010. 
Our study falls within the scope of the multidimensional measurement trend, and it presents an employment exclusion index that allows both identifying the dimensions or factors of employment exclusion and establishing a ranking of Spanish regions based on results.

Therefore, this paper contributes to the debate on social inequality in Spain [Ruiz-Huerta (2013); Ayala Cañón et al. (2018)], offering new results in relation to the observable regional disparities in the Spanish labour market, which have been highlighted in innumerable works, often from a descriptive perspective. In this sense, the four explanatory factors provided in this research complement the findings of other studies, such as the different educational levels [López-Bazo and Motellón (2013)] or the economic and institutional factors accounting for wage differences across regions [Davia Rodríguez (2013)]. Additionally, both the methodology used in the construction of the multidimensional indicator and the analysis perspective, based on the measurement of employment exclusion, are novel aspects with respect to the previously mentioned works carried out in Spain, either by being oriented to the measurement of the quality of employment [Merino Llorente et al. (2012); INE (2018b)], or by adopting a microanalysis approach in relation to employment vulnerability [Felgueroso et al. (2017); Felgueroso (2018)].

\section{Methodology}

The employment dimension is usually included in every system of social indicators, or in the resulting composite index, whose intention is to account for the complexity of social reality. However, the measurement model always starts from a previously stated conceptualization. For instance, the Social Progress Index, an indicator to measure well-being in European regions, does not include employment/unemployment variables because it excludes all economic measurements [Porter and Stern (2015), p. 26]. On the contrary, the Social Justice Index covers a long list of employment-related variables in its dimension Labor market access, which even doubles the weight of other areas of the index [Schraad-Tischler et al. (2017)].

We have taken the steps recommended by OECD (2008) to build our social exclusion index to ensure internal coherence and robust results. The method used is factor analysis because it enables us to condense a large number of explanatory variables into a set of latent factors or variables, with the smallest loss of information possible. This is how the relevant factors shaping employment exclusion are revealed. Factor analysis also allows the possibility of extracting the structure of weights with which they are to be aggregated to the global index. Therefore, factor analysis avoids previous judgements on the internal structure of the composite index, as it also includes a statistical criterion to assign weightings in the aggregation[3].

Factor analysis has been conducted to obtain the structure of relevant indicators measuring living standards and material deprivation [Callan et al. (1993); Guio (2005)]. It has been recently used to measure the components underlying the multidimensional concept of social exclusion [Bailey et al., 2017], including its relational dimension [Loktieva (2016)]. In Spain, Gallego and Subirat (2011) used factor analysis to identify the determinants of the sociostructural reality of the autonomous communities, and Jurado Málaga and Pérez-Mayo (2012), to construct a multidimensional index of wellbeing.

As this study is a regional analysis of employment exclusion, all the data available are collected in a matrix where the rows represent the regions and the columns represent the variables $\left(X_{i}\right)$. The size of the matrix is $n x m$, where $n$ is the number of regions and $m$ is the number of variables. Given the usually high number of variables, $m$, it is required to apply a
Employment exclusion in Spain 
AEA

27,80 factor analysis. The objective is to reveal the latent factors accounting for the correlation among variables. Each observed variable is a linear combination of factors plus a random residual component, without any correlation among residuals. More specifically, the factor analysis model is defined as follows:

$$
X_{i}=c_{i 1} f_{1}+c_{i 2} f_{2}+\ldots+c_{i m} f_{m}+d_{\mathrm{i}} e_{i}
$$

where $f_{i}$ are the common factors; $e_{i}$ are the unique factors and $c_{i j}$ is the weight of factor $j$ in variable $i$, called factor loading.

Variance of variable $\mathrm{X}_{\mathrm{i}}$ can be decomposed into two parts:

$$
\sigma_{i}^{2}=h_{i}^{2}+w_{i}^{2}
$$

$h_{i}^{2}$ being the proportion of each variable's variance that can be explained by the common factors and is called communality (defined as the sum of squared factor loadings for all variables), and $w_{i}^{2}$ being the percentage of variance for the variable that is not explained by the common factors, called uniqueness.

Sometimes, the factor solution has a complex interpretation and a rotation is performed so that the variables are highly correlated with one factor, and less with the others. This facilitates the interpretation of factors based on the meaning of the variables that most correlate with them. Varimax is the most commonly used rotation method to obtain factors that have a strong correlation with a small number of variables, and a weak one with the others, so the variance of factors is redistributed.

Some minimum criteria are needed to conduct factor analysis. These are Bartlett's test of sphericity and the KMO index [Kaiser-Meyer-Olkin]. Bartlett's test of sphericity checks that the correlation matrix is the identity matrix, which would indicate that there is no significant correlation among variables. When the $p$-value associated to this test is lower than 0.05 , is appropriate to conduct factor analysis. When KMO values are close to 1 , the sample is proved adequate, which means that the coefficients of partial correlation among original variables are small. On the other hand, the data are unsuitable for factor analysis when $K M O$ value is less than 0.5 .

The factors are selected by the Kaiser rule, which calculates the eigenvalues of the correlation matrix of original variables, and selects the factors with a value $>1$, taking into account the percentage of variance explained by factors, which must attain a satisfactory level (above 60 per cent). Each extracted factor has an average of 0 and a variance of 1 , their relevance being determined on the grounds of the variance percentage explained $\left(w_{j}\right)$. These latent variables must have a clear interpretation within the dimension of employment exclusion. When the variables of the extracted factor have a direct relationship with the risk of exclusion, it is called positive factor. And when the factor is inversely related to the risk of exclusion, it is called negative factor[4].

The following criterion has been applied to positive factors so that all factors are dimensionless and have the same variation range:

$$
f_{i j}^{+}=\frac{f_{i j}-\min \left(f_{j}\right)}{\max \left(f_{j}\right)-\min \left(f_{j}\right)}
$$


whereas for negative factors:

$$
f_{i j}^{-}=\frac{\max \left(f_{j}\right)-f_{i j}}{\max \left(f_{j}\right)-\min \left(f_{j}\right)}
$$

Employment exclusion in Spain

$f_{i j}$ being the value of factor $j$ in region $i$; and $f_{j}$, the vector made up of all regional values of factor $j$.

This change allows for a linear transformation so that all values are within the interval $[0,1]$. Therefore, regions with higher risk of exclusion in one factor will get 1 in such factor, and regions where risk of exclusion is lower will get 0 , regardless of whether the factor is positive (direct relationship) or negative (inverse relationship). This permits a comparative analysis across regions and a ranking of results. The region with the smallest value (0) has the lowest level of exclusion and would be the ideal region in that factor. The aim now is to determine the distance between every region, in each one of the factors, and the group of ideal regions for the factors shaping the dimension. To that end, the Euclidean distance of every region $i$ to the ideal region is estimated:

$$
d\left(\text { region }_{\mathrm{i}}, \text { ideal region }\right)=\left[\sum_{j=1}^{k} w_{j}^{2}\left(f_{i j}^{ \pm}-f_{i j}^{i d e a l}\right)^{2}\right]^{1 / 2} .
$$

In conclusion, we obtained a synthetic indicator which classifies regions based on their proximity to the ideal one by considering the cluster of factors found. This methodological choice of selecting the best regional achievement instead of the national average is due to our will to better capture regional disparities.

\section{Results}

This section presents the results obtained after applying the methodology, as well as the variables introduced in the model, the resulting explanatory factors, the temporal evolution of their mean values, territorial disparities in each of them, and finally the synthetic indicator that accounts for social inequality in the research field under study.

\section{Set of initial variables}

The initial selection of variables related to the risk of social exclusion in the employment dimension took into account the variables used in the already-mentioned international systems of social indexes or indicators of quality of life [OECD (2014a, 2014b); European Commission (2015), Eurostat (2017)], and in the literature on social exclusion in Spain and its regions [Subirats (2005); Gallego and Subirats (2011); Fundación FOESSA (2014)]. When collecting variables, special attention was paid to the indicators accounting for job insecurity, such as temporality, accident rate, work intensity or low pay, as well as some institutional aspects like flexible working arrangements or the coverage of collective bargaining, following Gallego and Subirats (2011).

The data on 25 variables (Table I) were collected from the surveys of the Spanish National Statistics Institute on Labour Force and Living Standards, as well as the surveys of the Ministry of Employment and Social Security on Registered Labour Movement, Employment Regulation and Affiliation of Workers to the Social Security System. A few variables not available at a regional level were constructed from the microdata of the Living Standards Survey, such as the percentage of employees earning less than the minimum wage, and the percentage of full-time and part-time working poor. When possible, variables 
Variables Source

Percentage of employees with fixed-term contracts

Percentage of employees with open-ended contracts

Labour Force Survey,

Economic activity rate by age, sex and nationality

Spanish National

Employment rate by age, sex and nationality

\section{4}

Unemployment rate by sex, gender and nationality

Percentage of employers with respect to number of self-employed workers

Percentage of family assistance with respect to number of self-employed workers

Percentage of independent workers with respect to number of self-employed

workers

Percentage of members of a cooperative with respect to number of self-employed workers

Percentage of employees with respect to total number of economically active persons

Percentage of wage-earners in the public sector with respect to total number of employees

Percentage of part-time workers with respect to total number of economically active persons

Percentage of households with low work intensity (when the ratio between the total number of months that all working-age household members have worked and the total number of months the same household members theoretically could have worked is below 0.2 )

Percentage of employees earning less than the minimum interprofessional wage

Percentage of working poor (income $60 \%$ lower than national median wages)

Percentage of full-time working poor

Percentage of part-time working poor

Rate of work accidents (number of work accidents per 1,000 inhabitants)

Percentage of open-ended contracts over total number of contracts

Percentage of fixed-term training contracts over total number of contracts

Percentage of fixed-term contracts turned into open-ended contracts over total number of contracts

Percentage of contracts to disabled workers over total number of contracts

Statistics Institute

Percentage of workers affected by procedures of collective redundancy (ERE) over

total number of workers contributing to the Social Security system

Percentage of workers participating in strikes over total number of workers

contributing to the Social Security system

Table I.

Percentage of workers affected by collective agreements over total number of

Initial variables workers contributing to the Social Security system

Living Conditions

Survey, Spanish

National Statistics

Institute

\author{
Registered Labour \\ Movement, Spanish \\ Ministry of \\ Employment and \\ Social Security
}

such as employment and unemployment rates were broken down by sex, age or nationality, with the aim of analysing these axes of social inequality.

In conclusion, the information matrix is made up of this series of variables for each autonomous community and city in every year of the period under study (2009-2014).

\section{Calculation of exclusion factors}

First, the minimum requirements to run the factor analysis were checked: the KMO value was equal to 0.775 , and Bartlett's sphericity test was significant $(\phi$-value $=0.000)$. The communalities, which represent the coefficient of multiple linear correlation of each variable[5] with the factors, are high (Table II), implying that all variables are very well represented in the factor space. 
V1: Foreign-born unemployment rate

V2: Unemployment rate in people aged under 25

V3: Employment rate in people aged 25-54

V4: Employment rate in people aged under 25

V5: Unemployment rate in people aged 25-54

V6: Percentage of households with low work intensity

V7: Percentage of employees earning less than minimum wage

V8: Percentage of working poor

V9: Unemployment rate in people aged over 54

V10: Percentage of contracts to disabled people over total contracts

V11: Rate of work accidents

V12: Percentage of employees with fixed-term contracts

V13: Percentage of employees with open-ended contracts

V14: Employment rate in people aged over 54
0.824

0.913

0.922

0.886

0.930

0.779

0.862

0.778

0.821

0.671

0.706

0.797

0.867

0.814
Employment exclusion in Spain

135

Table II.

Communalities

Source: Own elaboration

The optimum number of factors was given by the Kaiser rule, which determined the extraction of four factors, using Varimax rotation to facilitate the interpretation. Table III shows the variables that correlated with all four factors that account for nearly 83 per cent of data variability; $w_{j}$ being the percentage of variance explained by factor $j$ divided by the overall explained variance.

\begin{tabular}{|c|c|c|c|c|c|}
\hline \multirow[b]{2}{*}{ Factors and variables } & \multicolumn{4}{|c|}{ Factors } & \\
\hline & 1 & 2 & 3 & 4 & \\
\hline \multicolumn{6}{|l|}{ Unemployment factor } \\
\hline Foreign-born unemployment rate & 0.895 & -0.105 & 0.015 & -0.109 & \\
\hline Unemployment rate in people aged under 25 & 0.852 & 0.355 & -0.243 & 0.044 & \\
\hline Employment rate in people aged $25-54$ & -0.851 & -0.388 & -0.207 & 0.070 & \\
\hline Employment rate in people aged under 25 & -0.821 & -0.080 & 0.325 & 0.155 & \\
\hline Unemployment rate in people aged $25-54$ & 0.788 & 0.355 & -0.028 & 0.000 & \\
\hline Percentage of households with low work intensity & 0.783 & 0.399 & -0.035 & -0.070 & \\
\hline \multicolumn{6}{|l|}{ Income insecurity factor } \\
\hline Percentage of employees earning less than minimum wage & 0.074 & 0.901 & -0.028 & -0.212 & \\
\hline Percentage of working poor & 0.290 & 0.794 & 0.113 & -0.223 & \\
\hline Unemployment rate in people aged over 54 & 0.260 & 0.763 & -0.133 & -0.097 & \\
\hline \multicolumn{6}{|l|}{ Job insecurity factor } \\
\hline Percentage of contracts to disabled people over total contracts & -0.033 & 0.066 & -0.800 & 0.161 & \\
\hline Rate of work accidents & -0.310 & 0.004 & 0.780 & 0.051 & \\
\hline Percentage of employees with fixed-term contracts & 0.202 & 0.297 & 0.573 & -0.225 & \\
\hline \multicolumn{6}{|l|}{ Standard employment factor } \\
\hline Percentage of employees with open-ended contracts & -0.279 & -0.085 & -0.164 & 0.869 & \\
\hline Employment rate in people aged over 54 & 0.142 & -0.356 & -0.016 & 0.817 & \\
\hline$\%$ of explained variance & 33.56 & 22.69 & 13.72 & 12.73 & \\
\hline Weights $\left(\mathrm{w}_{\mathrm{j}}\right)$ & 0.4061 & 0.2740 & 0.1658 & 0.1541 & $\begin{array}{l}\text { Table III. } \\
\text { component }\end{array}$ \\
\hline Source: Own elaboration & & & & & matrix \\
\hline
\end{tabular}


AEA

27,80

The first factor, named Unemployment, reveals the impact that the general conditions of the labour market, in terms of unemployment and employment (the latter with negative values in the matrix coefficients, which indicates an inverse influence of unemployment on the risk of exclusion) have on employment exclusion. By referring only to unemployment, we seek to avoid possible misunderstandings regarding the positive relationship of this factor as a whole with exclusion in the employment dimension; that is, the direct relationship between this factor and exclusion (the higher the factor value, the higher the risk). This factor clusters employment and unemployment rates in the youth (people under the age of 25) and in people aged between 25 and 54, coupled with the foreign-born unemployment rate and the percentage of households with low work intensity.

The differentiation of employment and unemployment by sex and foreign origin (from the EU or non-community origin) has become irrelevant in the first factor because these variables are all associated with that factor. Only age differentiation in the over 54-year-old group has linked unemployment and employment rates to factors other than the first one.

The second factor is Income Insecurity, which involves low wages in general and unemployment in people aged over 54. Therefore, the vulnerability of older unemployed people, who have suffered the cutbacks in the duration and amounts of unemployment benefits during the crisis, is associated with the economic insecurity arising from income poverty and very low wages.

The third factor was called Job Insecurity, which gathers variables such as work accident rate, temporary work and the access of disabled people to the labour market. The latter has a negative coefficient in the matrix of rotated components (the higher the hiring of disabled people, the lower the risk of employment exclusion), whereas the other two variables have a positive relationship with employment exclusion (increased rates of temporary work and work accidents lead to higher risk of exclusion).

And finally, the fourth factor is Standard Employment according to the term used by the International Labour Organization to refer to the traditional functions of the employment relationship (stability, predictable and reliable incomes, safe workplaces, social protection, etc.) that enable work to satisfy a person's fundamental needs [ILO (2016), pp. 10-15]. This last factor involves a better inclusion in the labour dimension and it is defined by the percentage of employees with indefinite contracts and the employment rate in people aged over 54 . The over-54 group at large exhibits employment and unemployment rates under the average of the overall working-age population. This is due to the lower participation of women in this age bracket and the proximity to retirement. Higher job security rates, less temporary work, and a wide percentage of wage-earners in the public sector, especially women, are found in this age group [CES (2014), pp. 39-42; SEPE (2015), p. 37].

Thus, the first three factors apprehend precariousness in the labour market, describing the increasing insecurity and vulnerability of workers [Koukiadaki and Katsaroumpas (2017), p. 19]. In contrast, employment and income security, linked to an indefinite employment relationship, are represented in the fourth factor.

\section{Temporal and spatial evolution of exclusion factors}

Figure 1 shows the trend of the mean values of the exclusion factors obtained in the employment dimension between 2009 and 2014. Factors 3 and 4, Job Insecurity and Standard Employment, underwent a decrease in their mean values, more sharply in the former and very slightly in the latter.

The reduction of the mean value of Job Insecurity, which promotes lower employment exclusion, is due to a slight improvement in its three components between 2009 and 2014: decreased rates of temporary work and work accidents coupled with increased rates of 


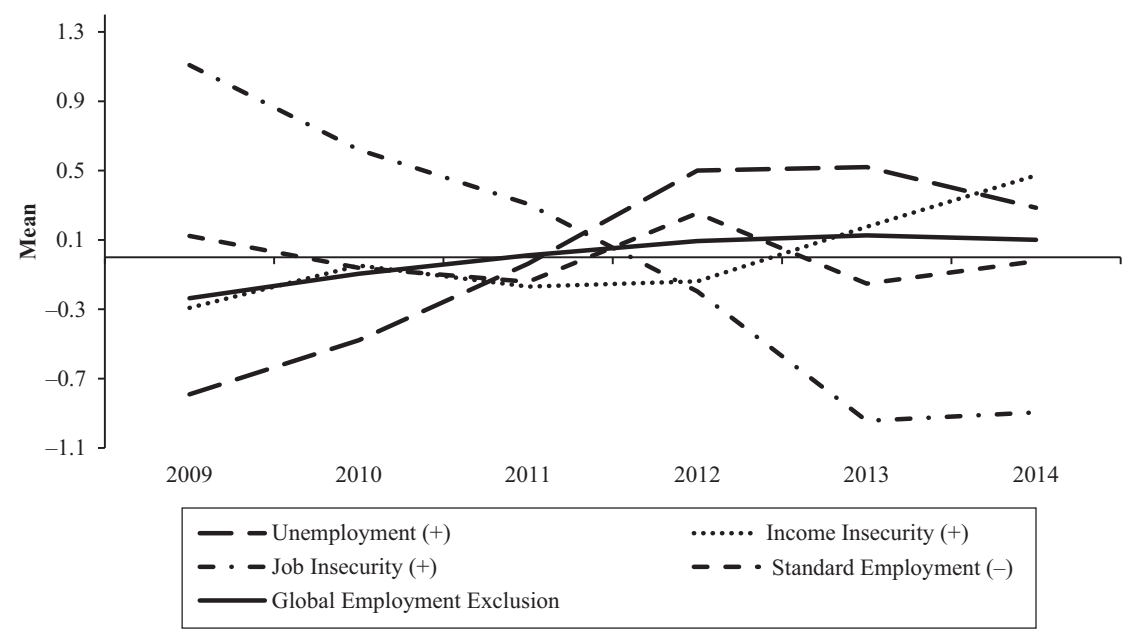

Notes: $(+)$ Direct relationship with employment exclusion (the higher the factor value, the higher the exclusion); (-) Inverse relationship with employment exclusion (the higher the factor value, the lower the exclusion)

Source: Own elaboration
Employment exclusion in Spain

Figure 1.

Temporal evolution of mean values by factors

labour market inclusion for individuals with a disability. The evolution of these three variables is visible in the national territory as a whole and in most regions. Nevertheless, there is an upturn in the mean value of this factor in 2014[6] leading to a change in trend.

On the other hand, the slight decrease in the mean value of the Standard Employment factor shows a more erratic course, with ups and downs throughout the period under analysis. On the contrary, there is a rise in the mean values of factors 1 and 2, Unemployment and Income Insecurity, in the same period, which worsens the conditions of the employment dimension. As a result, the rising trend of the global mean value of all factors implies the worsening of employment exclusion in the period under analysis[7].

Regional differences are shown in Figure 2, the most noticeable ones being found in Income Insecurity and Standard Employment. Likewise, Ceuta and Melilla show the most differing mean values of Unemployment with respect to the other regions. The graphical analysis gives an account for the positions of the autonomous communities and cities regarding their performance in every employment exclusion factor. It also provides the number of regions located in each factor according to whether they are pro or against exclusion. Most regions lean towards exclusion in the negative factor Standard Employment, as 12 regions have values below 0 (mean value of the factor). This implies that the fourth factor increases employment exclusion in most of the Spanish territory. There are fewer regions with values over zero in the remaining factors, which are all positive: Unemployment (6) and Income Insecurity (7). Job Insecurity (9) displays a more even distribution.

Consequently, the group of regions that could worsen the risk of employment exclusion is smaller than the number of regions that could diminish it by reducing or improving the positive factors. However, the fact that Andalusia is in the small group of regions with a positive impact on the risk of employment exclusion counteracts this situation, given its demographic weight. 
AEA

27,80

\section{8}

Figure 2.

Mean value of factors across regions
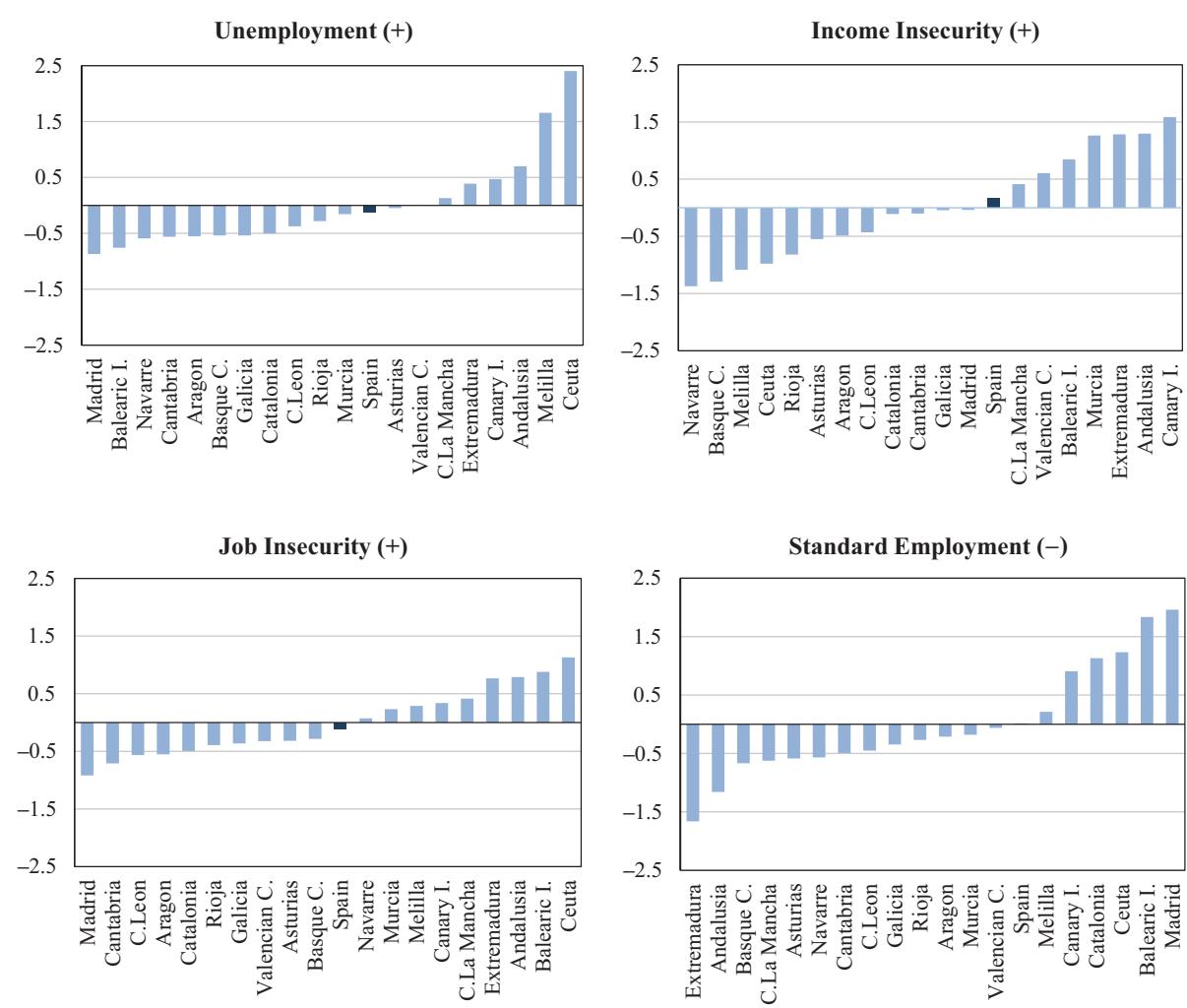

Notes: $(+)$ Direct relationship with employment exclusion (the higher the factor value, the higher the exclusion); (-) Inverse relationship with employment exclusion (the higher the factor value, the lower the exclusion)

Source: Own elaboration

In any case, it seems obvious that the Spanish policies against employment exclusion must be implemented by the majority of autonomous communities and cities, so that the indicators related to the employment factors obtained are strengthened; the positive factors should be reduced and the negative factor should be increased.

\section{Employment exclusion index}

The nature of each factor must be taken into account to achieve a global indicator of employment exclusion. As previously said, the first three factors contribute to employment exclusion (positive factors) whereas the fourth one (negative) behaves inversely (the higher the value, the lower the exclusion). The transformations necessary for all four factors to be interpreted in the same way were performed by expressions (3) and (4) (Table IV).

Madrid gets the lowest value in three factors (Unemployment, Job Insecurity and Standard Employment), whereas Navarre has the lowest value in Income Insecurity. The highest values in Unemployment and Job Insecurity are found in Ceuta; and the maximum values in Income Insecurity and Standard Employment are registered in the Canary Islands 


\begin{tabular}{|c|c|c|c|c|c|}
\hline Region & Unemployment & Income insecurity & Job insecurity & Standard employment & Employment \\
\hline Andalusia & 0.4792 & 0.9024 & 0.8332 & 0.8610 & $\mathrm{C}_{m}$ \\
\hline Aragon & 0.0969 & 0.2997 & 0.1791 & 0.6001 & \\
\hline Asturias & 0.2510 & 0.2789 & 0.2931 & 0.7030 & \\
\hline Balearic Islands & 0.0340 & 0.7503 & 0.8781 & 0.0346 & \\
\hline Basque Country & 0.1010 & 0.0278 & 0.3094 & 0.7257 & \\
\hline Canary Islands & 0.4092 & 1.0000 & 0.6133 & 0.2909 & 139 \\
\hline Cantabria & 0.0939 & 0.4301 & 0.1017 & 0.6773 & \\
\hline Castile and Leon & 0.1507 & 0.3187 & 0.1728 & 0.6656 & \\
\hline Castilla-La Mancha & 0.3056 & 0.6039 & 0.6503 & 0.7139 & \\
\hline Catalonia & 0.1120 & 0.4270 & 0.2072 & 0.2288 & \\
\hline Ceuta & 1.0000 & 0.1337 & 1.0000 & 0.2012 & \\
\hline Extremadura & 0.3843 & 0.8975 & 0.8218 & 1.0000 & \\
\hline Galicia & 0.1016 & 0.4500 & 0.2705 & 0.6371 & \\
\hline Madrid & 0.0000 & 0.4520 & 0.0000 & 0.0000 & \\
\hline Melilla & 0.7720 & 0.0977 & 0.5895 & 0.4827 & \\
\hline Murcia (Region of) & 0.2177 & 0.8905 & 0.5614 & 0.5906 & \\
\hline Navarre & 0.0848 & 0.0000 & 0.4836 & 0.6980 & \\
\hline Rioja (La) & 0.1798 & 0.1869 & 0.2565 & 0.6151 & \\
\hline Valencian C & 0.2668 & 0.6684 & 0.2905 & 0.5580 & Table IV. \\
\hline Spain & 0.2285 & 0.5187 & 0.3953 & 0.5390 & ransformed \\
\hline \multicolumn{5}{|c|}{ Source: Own elaboration } & exclusion factors \\
\hline
\end{tabular}

and Extremadura, respectively. Therefore, the region with the lowest score is the ideal region for each factor: Navarre for Income Insecurity and Madrid for the other three factors. The highest values for Spain as a whole are found in Standard Employment and Income Insecurity.

Figure 3 shows the distance between every region and the ideal one in all four factors. The regions with the best positions are at the extreme points, in the outer part of the figure. The closer to the core of the graphic, the higher the risk of exclusion associated with each employment factor, compared to its ideal region. The Community of Madrid is the reference to calculate the distances of the rest of regions in three factors, and Navarre in the fourth one.

The employment exclusion index (Table V) was calculated by expression (5), from the transformed factors and once the ideal region was determined. This provides a ranking of regions.

The most advantageous positions are held by Madrid and the Basque Country; whereas the worst scores are found in Ceuta, Andalusia and Extremadura (Figure 4). The employment exclusion index for Spain is at an intermediate position with seven autonomous communities and the two autonomous cities with higher values.

These results suggest that regions group according to their ratings in the employment dimension. Madrid, Basque Country, Aragon, Catalonia, La Rioja and Navarre form the first group, with the lowest values (between 0.12 and 0.14). The second group includes Castile and Leon, Cantabria, Galicia and Asturias, which are close to the former group, their values being 20-40 per cent higher than the lowest value (Madrid). The remaining regions show values far too high compared to these two groups, especially Andalusia and Extremadura, whose indicators practically triple the index of the best placed region, and Ceuta, where there is a 256 per cent increase.

These findings are consistent with previous research, although they refer to different time periods and adopt a different analytical perspective. Merino Llorente et al. (2012) 
AEA

27,80

140

Figure 3.

Exclusion factors

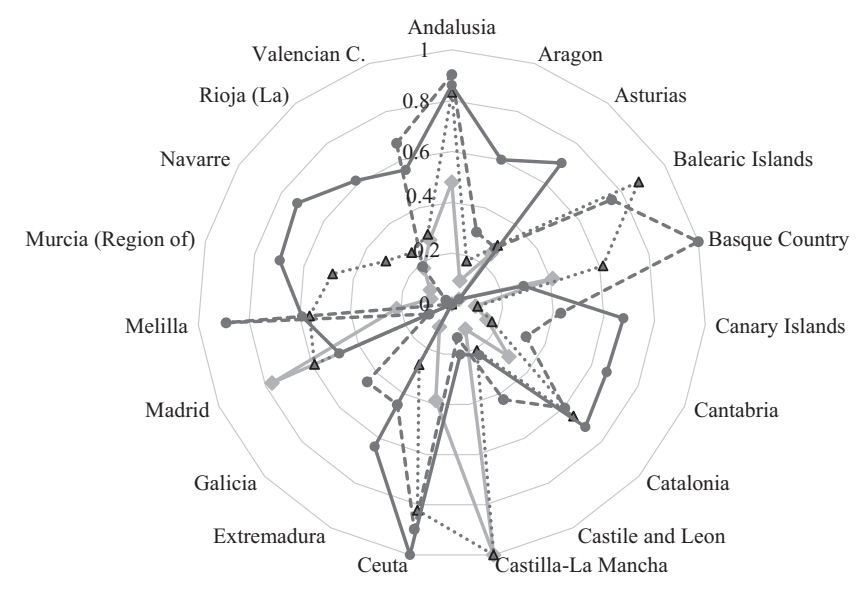

$\longrightarrow$ Unemployment $(+) \quad-\infty--$ Income Insecurity $(+) \cdots \Delta \cdots$ Job Insecurity $(+) \multimap$ Standard Employment $(-)$
Andalusia

Aragon

Asturias

Balearic Islands

Basque Country

Canary Islands

Cantabria

Castile and Leon

Castilla-La Mancha

Catalonia

Ceuta

Extremadura

Galicia

Madrid

Melilla

Murcia (Region of)

Navarre

Rioja (La)

Table V.

Employment exclusion index
Valencian C

Spain

Source: Own elaboration
0.3684

0.1331

0.1741

0.2524

0.1299

0.3392

0.1628

0.1507

0.2579

0.1348

0.4412

0.3566

0.1690

0.1239

0.3378

0.2904

0.1385

0.1369

0.2345

0.2000

highlight the weakening in the levels of employment quality in the autonomous communities between 2007 and 2010, which diverge because of the increased regional disparities due to the crisis. More recently, in Felgueroso (2018), the most vulnerable population with regard to employment for the year 2017 is distributed across the Spanish territory in a very similar manner as our employment exclusion index for the period of crisis. 


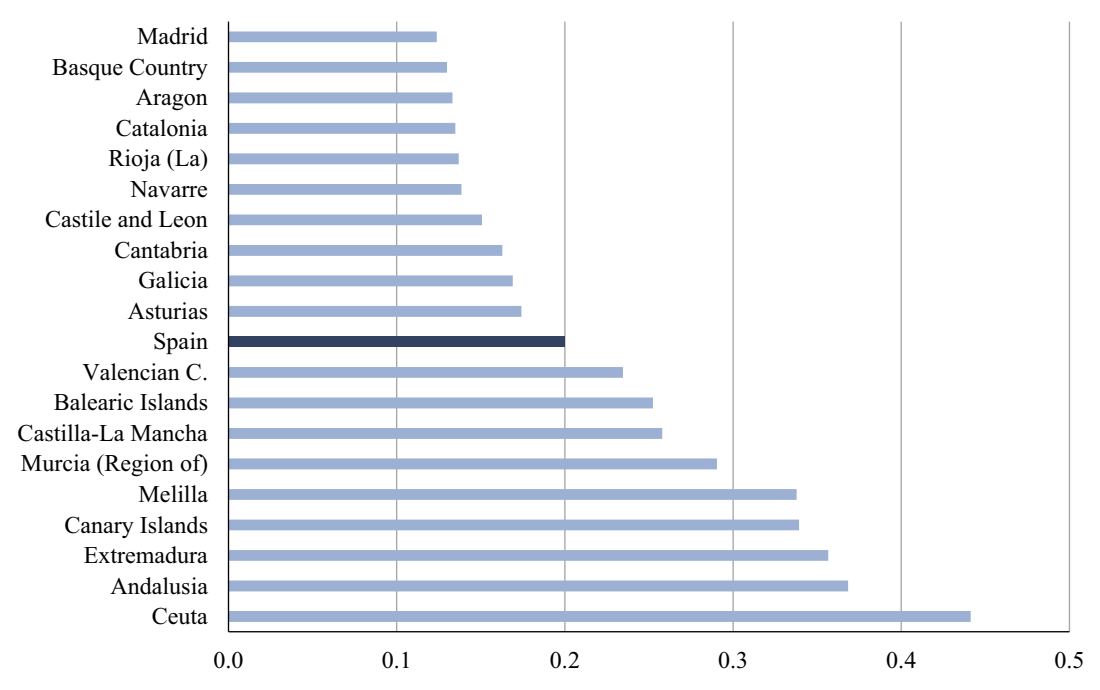

Source: Own elaboration
Employment exclusion in Spain

Figure 4.

Employment exclusion index ranking

Likewise, the regions with higher quality of life at work according to INE (2018b) for 2017 are the regions with lower employment exclusion rates revealed by this study. Therefore, the positions of autonomous communities in relation with employment exclusion remain despite the recent economic revival.

To ensure consistency in the results, the calculation of employment exclusion is reproduced for each year between 2009 and 2014, analysing their annual evolution (Figure 5). It can be seen that the territorial positions remain stable every year of the period under analysis, with a significant Spearman's correlation coefficient over 0.9 in all the cases. This

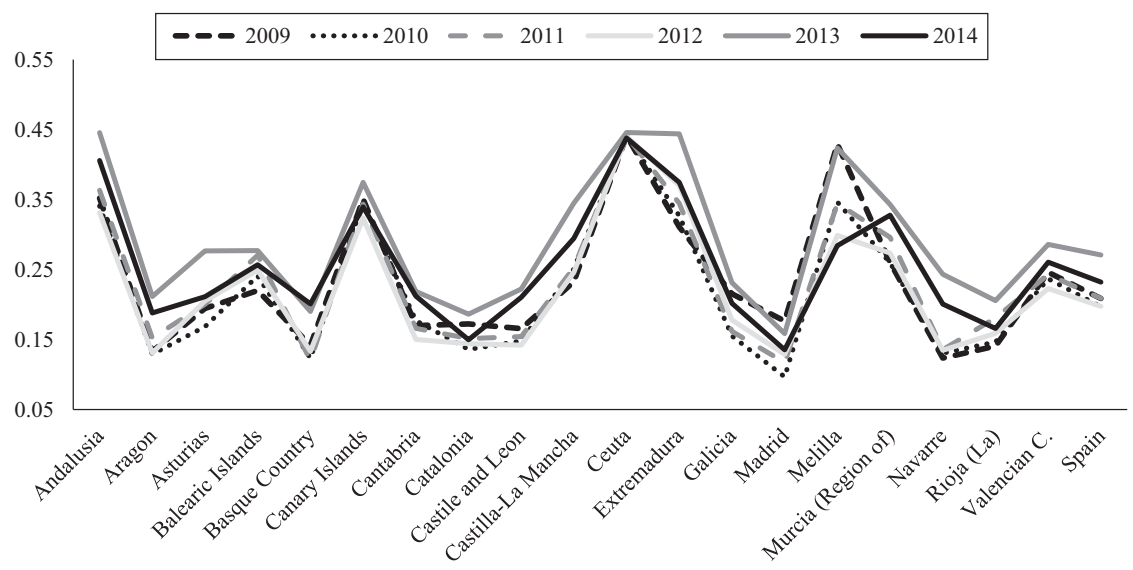

Source: Own elaboration

Figure 5. Temporal evolution of the Employment exclusion index 
AEA

27,80

\section{2}

corroborates the validity of the method used to build an employment exclusion index that allows analysing the evolution of multiple variables in the years of economic crisis, synthesised in a single figure.

Finally, the explanatory power of our employment exclusion index is corroborated by its strong links to the regional risk of poverty or social exclusion measured by the AROPE rate (Figure 6). However, it should be considered that employment exclusion is integrated in the AROPE rate through the indicator population living in (quasi-)jobless households, and it may also influence its most important component, being at risk of poverty, through working poverty.

As it could be expected, increased regional values of the employment exclusion index are associated with increased levels of poverty or social exclusion. The case of Navarre is noticeable because its employment exclusion index is higher than other regions, but it also has the lowest risk of poverty or social exclusion, due to the fact that this community has the best results in social policies. As for Ceuta and Melilla, they are far from the trend because of their specificity.

\section{Conclusions}

This paper contributes to the discussion on regional disparities regarding employment exclusion under an approach of multidimensional analysis, more commonly used in national comparative studies. The factors shaping risk of employment exclusion are Unemployment, Income Insecurity, Job Insecurity and Standard Employment, identified by a factor analysis conducted on a wide set of indicators taken from different sources of information. The first three are positive (the higher the factor value, the higher the risk), whereas the latter is negative (the higher the value, the lower the risk).

Unemployment is the factor that accounts for the variability of regional data to a greater extent. The most noticeable differentiation shaping this factor is observed in the age groups of employment and unemployment rates in the young and adults aged up to 55. While the first factor explains regional disparities with regard to quantity of employment available, the other three factors account for aspects related to quality of employment. Therefore, the results point out the need for considering some aspects of the labour market that are more

Figure 6.

Link between Employment exclusion index and AROPE rate

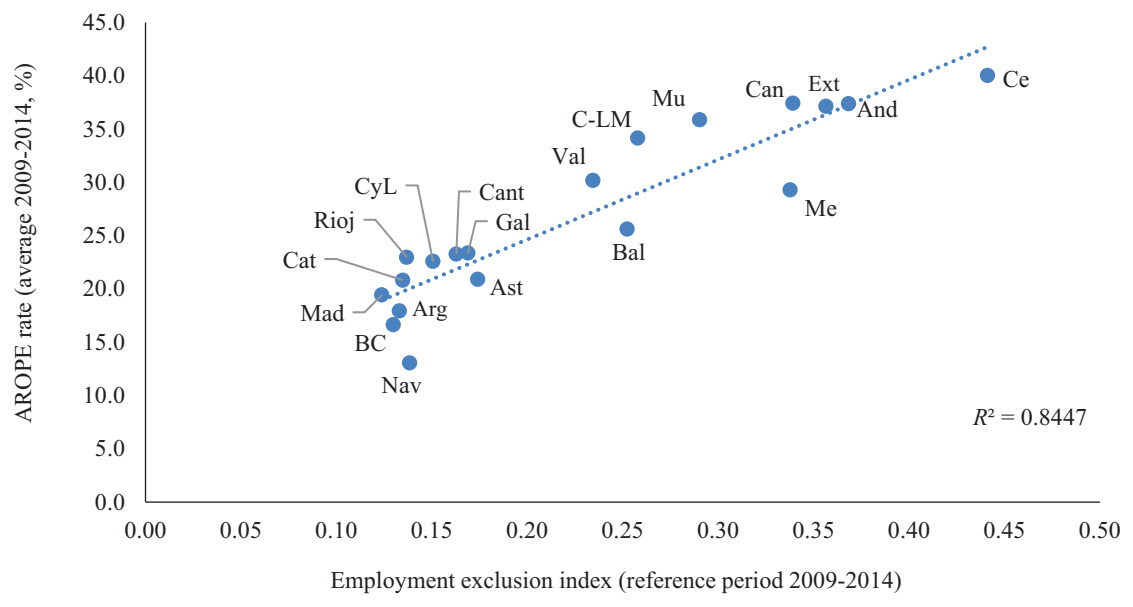

Source: Own elaboration 
associated with working conditions such as income, stability or security, in addition to the problems in the access to the labour market, usually represented by the unemployment rate.

Furthermore, the remarkable increase in the risk of social exclusion in the employment dimension between 2009 and 2014 has been confirmed. This trend is due mainly to the bad performance of the variables associated with two explanatory factors for this dimension (Unemployment and Income Insecurity), which keep growing throughout the period under analysis.

A synthetic employment exclusion index was constructed to rank the Spanish regions. The interpretation is simple: the lower the value, the more reduced the risk of exclusion. Ceuta, Andalusia, Extremadura, the Canary Islands, Melilla and the Region of Murcia are the lowest ranked regions, whereas Madrid, Basque Country, Aragon, Catalonia, La Rioja and Navarre hold the best positions.

This classification is to be regarded in relative terms, as it takes the best results of one region, the ideal one, as a reference, but it does not mean that such region has an optimal problem-free social framework. Instead, the methodology applied in the construction of the employment exclusion index underlines the measurement of territorial disparities. This facilitates an approach to research on the causes for the observed distances, especially on the possible differences regarding the regional policy measures implemented.

The territorial disparities in employment exclusion remain despite the recovery of the labour market, which is in line with other recent studies [Felgueroso (2018); INE (2018b)]. The persistent employment vulnerability has a negative effect not only on the people concerned but also on potential growth and social cohesion [Eurostat (2018); Eurofound (2018)]. Therefore, more accurate knowledge on the territorial disparities in Spain is crucial to raise awareness and tackle the problem without further delay.

Ultimately, results highlight the need for closing distances between regions, reducing the high risk of employment exclusion in many of them. Therefore, it is necessary to implement some measures by social and economic policies aiming at a more inclusive growth and reinforcing the social cohesion levels that were so badly damaged by the crisis. Therefore, reduced unemployment rates, which are expected to continue falling if the economic recovery goes on, are not enough to diminish the risk of employment exclusion, but instead it is income conditions and stability in labour relations that need to be improved. To that end, it seems necessary not only to enhance government coordination at national, regional and local levels but also to take alternative approaches, as suggested by Iammarino et al. (2017), who recommend the implementation of placesensitive distributed development policies that consider the structural potentials and limitations of every territory.

\section{Notes}

1. This indicator has met with criticism due to some methodological weaknesses and the appropriateness of the measurements. See Ponthieux (2017) for further information.

2. Working poverty does not only rely on low pay per hour but also on the household's low work intensity, size and composition [Eurofound (2017)].

3. Aggregation in composite indicators is a controversial issue. A common choice is equal weighting, where the same weight is given to the different dimensions and variables, previously normalised, within each dimension. This could result in an unbalanced structure of the composite index because the dimensions grouping the larger number of variables will have higher weight [OECD (2008), p. 31].

\section{Employment exclusion in Spain}


AEA

27,80

\section{4}

4. Meaning that an increase in the factor leads to a rise in the risk of exclusion (positive factor), or otherwise, an increase in the factor reduces or contributes negatively to the risk of exclusion (negative factor).

5. The variables showing a very low communality and a correlation with factors below 0.3 were dropped. The Appendix includes the mean values and standard deviation of the variables selected for the model by region in the period 2009-2014. V8 and V10 show the highest territorial dispersion, measured through the coefficient of variation, whereas the opposite occurs in V3 and V14.

6. For instance, according to the Labour Force Survey, the temporary work variable, which is included in the third factor, increased again in Spain as a whole and in almost every region between 2014 and 2016, together with the employment growth registered in this period (www.ine. es/jaxiT3/Datos.htm?t=4961).

7. After a non-parametric Kruskal-Wallis test, it is determined that changes in mean values are statistically significant in Unemployment and Job Insecurity, whereas they are not in Income Insecurity and Standard Employment.

\section{References}

Arundel, R. and Lennartz, C. (2018), "Dualization in labour markets and housing outcomes: insiders versus outsiders”, HOUWEL Working Paper no. 12.

Atkinson, A.B. (1998), "Social exclusion, poverty and unemployment", in Atkinson, A.B. and Hills, J. (Eds) Exclusion, Employment and Opportunity, LSE STICERD, Research Paper no. CASE004, pp. 1-24.

Ayala Cañón, L. (2008), "Crecimiento económico, políticas públicas y bienestar: ¿el cambio de un modelo?”, in Hernández Pedreño, M. (dir.) Exclusión Social y Desigualdad, Murcia, Editum, pp. 59-76.

Ayala Cañón, L., Cantó Sánchez, O., Martínez López, R., Navarro Ruiz, C. and Romaguera de la Cruz, M. (2018), Bienestar Económico y Material, Fundación Bancaria “la Caixa”, Palma de Mallorca.

Bailey, N., Fahmy, E. and Bradshaw, J. (2017), “The multi-dimensional analysis of social exclusion”, in Bramley, G. and Bailey, N. (Eds) Poverty and Social Exclusion in the UK: vol. 2 - the Dimensions of Disadvantage, Policy Press, Bristol, pp. 311-342.

Benach, J., Vives, A., Amable, M., Vanroelen, C., Tarafa, G. and Muntaner, C. (2014), "Precarious employment: understanding an emerging social determinant of health", Annual Review of Public Health, Vol. 35 No. 1, pp. 229-253.

Betcherman, G. (2012), "Labor market institutions: a review of the literature", World Bank, Policy Research Working Paper no. 6276.

Bradshaw, J., Kemp, P., Baldwin, S. and Rowe, A. (2004), The Drivers of Social Exclusion. A Review of the Literature for the Social Exclusion Unit in the Breaking the Cycle Series, Office of the Deputy Prime Minister, London.

Brandolini, A. and Viviano, E. (2017), "Extensive versus intensive margin: changing perspective on the employment rate", in Atkinson, A.B., Guio, A.-C. and Marlier, E. (Eds), Monitoring Social Inclusion in Europe, Publications Office of the European Union, Luxembourg, pp. 175-189.

Broughton, A., Green, M., Rickard, C., Swift, S., Eichhorst, W., Tobsch, V., Magda, I., Lewandowski, P., Keister, R., Jonaviciene, D., Ramos Martin, N.E., Valsamis, D. and Tros, F. (2016), Precarious Employment in Europe: Patterns, Trends and Policy Strategies, European Parliament, Brussels.

Callan, T., Nolan, B. and Whelan, C. (1993), "Resources, deprivation and the measurement of poverty", Journal of Social Policy, Vol. 22 No. 2, pp. 141-172.

Castel, R. (1995), Les Métamorphoses de la Question Sociale. Une Chronique du Salariat, Fayard, Paris. 
Cazes, S., Hijzen, A. and Saint-Martin, A. (2015), "Measuring and assessing job quality: the OECD job quality framework", OECD Working Papers, no. 174.

CES (2014), La Situación Sociolaboral de Las Personas de 45 a 64 Años de Edad, Consejo Económico y Social de España, Madrid.

Davia Rodríguez, M.A. (2013), "Mercado de trabajo y desigualdad”, in Ruiz-Huerta, J. (Ed.) 1er Informe Sobre la Desigualdad en España 2013, Fundación Alternativas, Madrid, pp. 75-133.

Davidsson, J. and Naczyk, M. (2009), "The ins and outs of dualisation: a literature review", RECWOWE Working Paper no. 2.

Eurofound (2013), Impact of the Crisis on Working Conditions in Europe, Publications Office of the European Union, Luxembourg.

Eurofound (2017), In-Work Poverty in the EU, Publications Office of the European Union, Luxembourg.

Eurofound (2018), Social Cohesion and Well-Being in Europe, Publications Office of the European Union, Luxembourg.

European Commission (2003), "Joint report on social inclusion-summarising the results of the examination of the national action plans for social inclusion (2003-2005)", COM(2003), p. 773.

European Commission (2010), The European Employment Strategy: Working to Improve Employment in Europe, Publications Office of the European Union, Luxembourg.

European Commission (2015), Portfolio of EU Social Indicators for the Monitoring of Progress towards the EU Objectives for Social Protection and Social Inclusion, Publications Office of the European Union, Luxembourg.

European Commission (2018a), "Monitoring the implementation of the european pillar of social rights", $\operatorname{COM}(2018)$, p. 130.

European Commission (2018b), Employment and Social Developments in Europe 2018, Publications Office of the European Union, Luxembourg.

Eurostat (2017), "Final report of the expert group on quality of life indicators", Publications Office of the European Union, Luxembourg.

Eurostat (2018), Smarter, Greener, More Inclusive? Indicators to Support the Europe 2020 Strategy2018 Edition, Publications Office of the European Union, Luxembourg.

Felgueroso, F. (2018), "Población especialmente vulnerable ante el empleo en españa en el año 2018", FEDEA Studies on the Spanish Economy, Vol. 11.

Felgueroso, F., Millán, A. and Torres, M. (2017), Población Especialmente Vulnerable Ante el Empleo en España. Cuantificación y Caracterización, FEDEA Studies on the Spanish Economy 07.

Frazer, H., Guio, A., Marlier, E., Vanhercke, B. and Ward, T. (2014), "Putting the fight against poverty and social exclusion at the heart of the EU agenda: a contribution to the Mid-Term review of the Europe 2020 strategy", OSE Research Paper no. 15.

Fulvimari, A. ; Grzegorzewska, M. and Salanauskaite, L. (2016), Labour market transitions, DG EMPL Analytical Web Note 1/2016.

Fundación FOESSA (2014), VII Informe Sobre Exclusión y Desarrollo Social en España, 2014, Fundación FOESSA, Madrid.

Gallego, R. and Subirats, J. (Eds) (2011), Autonomies i Desigualtats a Espanya: Percepcions, Evolució Social i Politiques de Bienestar, Institut d'Estudis Autonòmics, Generalitat de Catalunya, Barcelona.

Gordon, D., Edwards, R. and Reich, M. (1982), Segmented Work, Divided Workers: The Historical Transformation of Labor in the United States, Cambridge University Press, New York, NY.

Gradín, C., Cantó, O. and del Río, C. (2017), "Measuring employment deprivation in the EU using a household-level index", Review of Economics of the Household, Vol. 15 No. 2, pp. 639-667.
Employment exclusion in Spain 
AEA

27,80

Guio, A. (2005), Material Deprivation in EU. Eurostat, Statistics in Focus 21/2005, Publications Office of the European Union, Luxembourg.

Hernández Pedreño, M. (Ed.) (2008), Exclusión Social en la Región de Murcia, Editum, Murcia.

Hernández Pedreño, M. (Ed.) (2014), Evolución de la Exclusión Social en la Región de Murcia: repercusiones Sociales de la Crisis, Editum, Murcia.

Iammarino, S., Rodríguez-Pose, A. and Storper, M. (2017), "Why regional development matters for Europe's economic future”, European Commission Working Papers no. 7.

ILO (2016), Non-Standard Employment around the World: Understanding Challenges, Shaping Prospects, International Labour Office, Geneva.

ILO (2017), Inception Report for the Global Commission on the Future of Work, International Labour Office, Geneva.

ILO (2018), "Avoiding unemployment is not enough: an analysis of other forms of labour underutilization", Spotlight on Work Statistics n, Vol. 4.

INE (2018a), Indicadores de Calidad de Vida. Metodología, Instituto Nacional de Estadística, Madrid.

INE (2018b), Indicadores de Calidad de Vida. Análisis Multidimensional, Instituto Nacional de Estadística, Madrid.

Jurado Málaga, A. and Pérez-Mayo, J. (2012), "Construction and evolution of a multidimensional Well-Being index for the Spanish regions", Social Indicators Research, Vol. 107 No. 2, pp. 259-279.

Kalleberg, A.L. (2009), "Precarious work, insecure workers: employment relations in transition", American Sociological Review, Vol. 74 No. 1, pp. 1-22.

Koukiadaki, A. and Katsaroumpas, I. (2017), Temporary Contracts, Precarious Employment, Employees' Fundamental Rights and EU Employment Law, European Parliament, Brussels.

Lagas, P., van Dongen, F., van Rijn, F. and Visser, H. (2015), "Regional quality of living in Europe", REGION, Vol. 2 No. 2, pp. 1-26.

Lang, C., Schömann, I. and Clauwaert, S. (2013), "Atypical forms of employment contracts in times of crisis”, ETUI Working Paper no. 3.

Laparra Navarro, M., Obradors I Pineda, A., Pérez Eransus, B., Pérez Yruela, M., Renes Ayala, V., Sarasa Urdiola, S., Subirats, J. and Trujillo Carmona, M. (2007), "Una propuesta de consenso sobre el concepto de exclusión. Implicaciones metodológicas”, Revista Española Del Tercer Sector, Vol. 5, pp. 15-57.

Laparra Navarro, M., Zugasti Mutilva, N. and García Lautre, I. (2014), "Reflexiones metodológicas en el análisis de la exclusión social”, Fundación FOESSA, Documento de Trabajo 3.1.

Leahy, A., Healy, S. and Murphy, M. (2015), Poverty and Inequalities on the Rise. A Study of the Impact of the Crisis and Austerity on People, with a Special Focus on Cyprus, Greece, Ireland, Italy, Portugal, Romania and Spain, Caritas Europa, Brussels.

Levitas, R., Pantazis, C.H., Fahmy, E., Gordon, D., Lloyd, E. and Patsios, D. (2007), The MultiDimensional Analysis of Social Exclusion, University of Bristol, Bristol.

Loktieva, I. (2016), “Approaches to empirical analysis of social exclusion: international comparison”, Economics and Sociology, Vol. 9 No. 2, pp. 148-157.

López-Bazo, E. and Motellón, E. (2013), "Disparidades en los mercados de trabajo regionales. El papel de la educación”, Papeles de Economía Española, Vol. 138, pp. 46-61.

Lorente Campos, R. and Guamán Hernández, A. (2018), "Expansión de la temporalidad y erosión de la relación de empleo estándar en españa: ¿La irrupción de un nuevo paradigma de relación de empleo?”, Cuadernos de Relaciones Laborales, Vol. 36 No. 1, pp. 35-63.

Manzanera Román, S., Ortiz García, P. and Hernández Pedreño, M. (2016), "Crisis del factor trabajo como vía de integración social”, Cuadernos de Relaciones Laborales, Vol. 34 No. 1, pp. 15-35. 
Merino Llorente, M.C., Somarriba Arechavala, N. and Negro Macho, A.M. (2012), "Un análisis dinámico de la calidad del trabajo en españa. Los efectos de la crisis económica", Estudios de Economía Aplicada, Vol. 30 No. 1, pp. 261-282.

OECD (2008), Handbook on Constructing Composite Indicators: methodology and User Guide, OECD Publishing, Paris.

OECD (2014a), How's Life in Your Region? Measuring Regional and Local Well-Being for Policy Making, OECD Publishing, Paris.

OECD (2014b), Society at a Glance 2014: OECD Social Indicators, OECD Publishing, Paris.

OECD (2017), Bridging the Gap: Inclusive Growth 2017 Update Report, OECD Publishing, Paris.

OECD (2018), OECD Regional Well-Being: A User "s Guide, OECD Publishing, Paris.

Ponthieux, S. (2017), "Risk of poverty or social exclusion over time: a focus on (quasi-)joblessness", in Atkinson, A.B., Guio, A.-C. and Marlier, E. (Eds), Monitoring Social Inclusion in Europe, Publications Office of the European Union, Luxembourg, pp. 175-189.

Porter, M. and Stern, S. (2015), Social Progress Index 2015, Social Progress Imperative, Washington, DC.

Ruiz-Huerta, J. (Ed.) (2013), 1er Informe Sobre la Desigualdad en España 2013, Fundación Alternativas, Madrid.

Schraad-Tischler, D., Schiller, C., Heller, S.M. and Siemer, N. (2017), Social Justice in the EU-Index Report 2017, Bertelsmann Stiftung, Gütersloh.

SEPE (2015), Informe Del Mercado de Trabajo de Los Mayores de 45 Años, Servicio Público de Empleo Estatal, Madrid.

Standing, G. (2011), The Precariat: The New Dangerous Class, Bloomsbury Academic, London.

Subirats Humet, J. (Ed.) (2005), Análisis de Los Factores de Exclusión Social, Fundación BBVA, Bilbao.

Ward-Warmedinger, M. and Macchiarelli, C. (2013), "Transitions in labour market status in the EU", IZA Discussion Paper, Vol. 3 No. 17, p. 7814.

\section{Further reading}

Faura-Martínez, U., Lafuente-Lechuga, M. and García-Luque, O. (2016), "Risk of poverty or social exclusion: evolution during the economic crisis and territorial perspective", Revista Española de Investigaciones Sociológicas, Vol. 156, pp. 59-76.

\section{Corresponding author}

Matilde Lafuente-Lechuga can be contacted at: mati@um.es

Employment exclusion in Spain 
AEA

27,80

\section{8}

\section{Appendix}

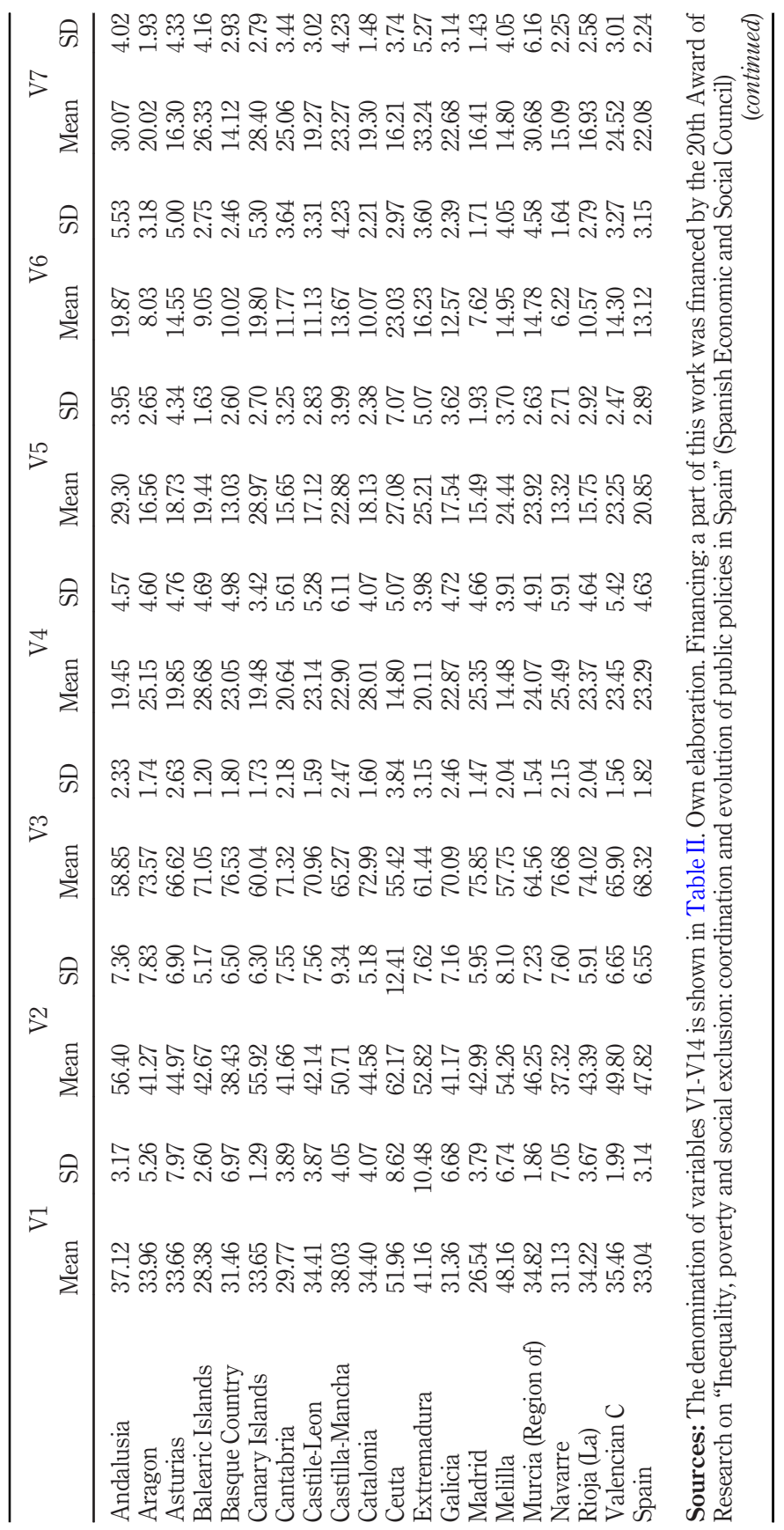

Table AI.

Mean and standard deviations of variables selected for factor analysis, 20092014 


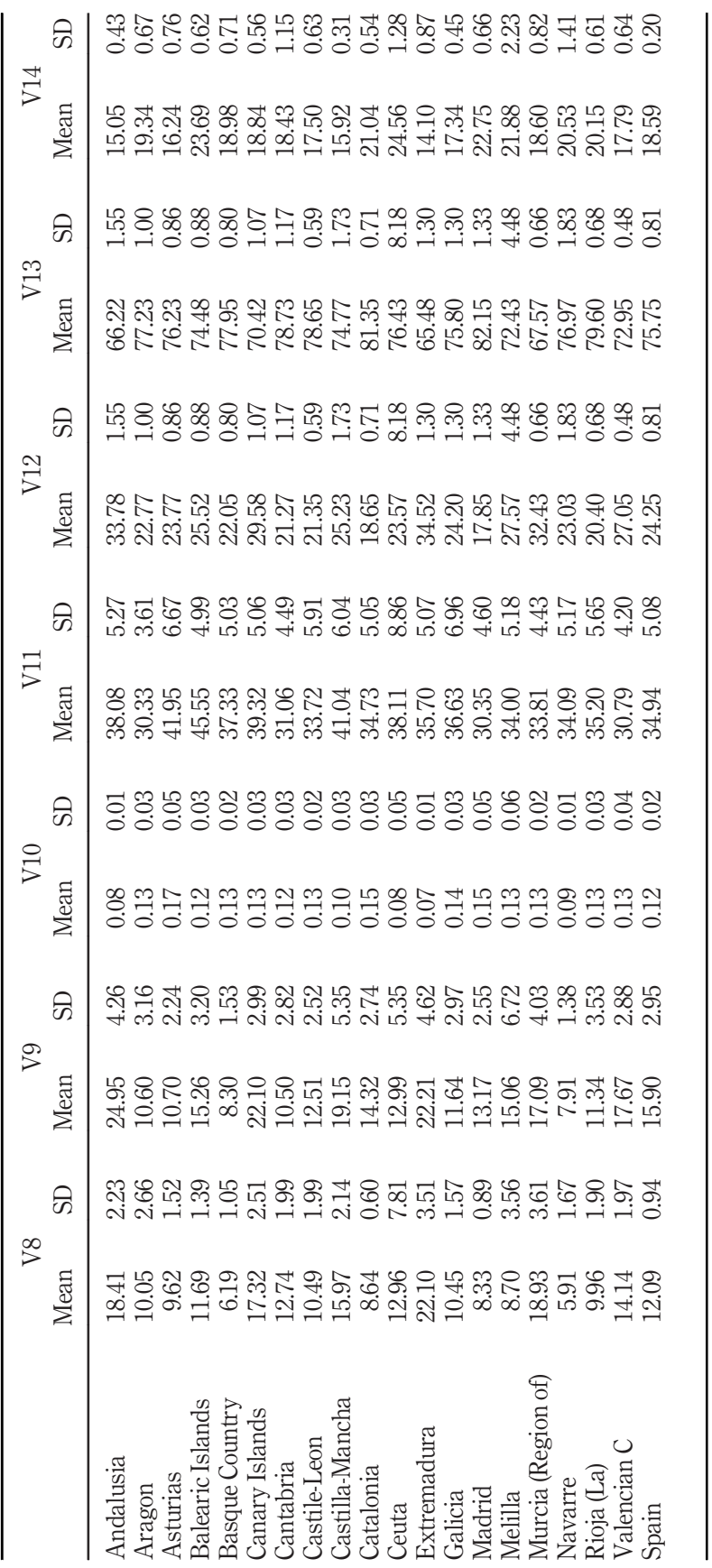

Employment

exclusion in

Spain

m

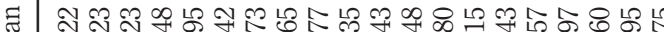

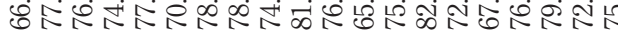

눈 \&

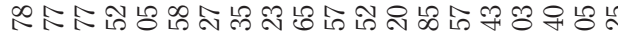

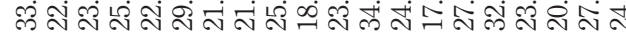

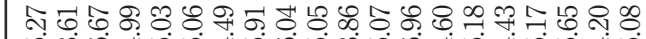

ஊ ๓

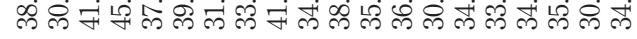

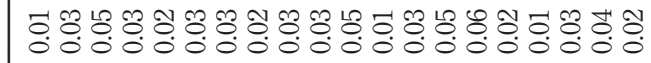

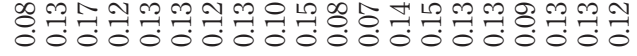

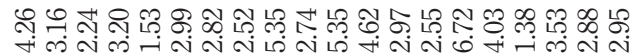

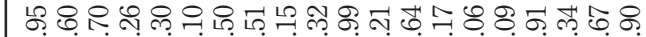

ํํㅇํㅇำ

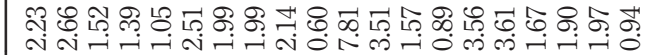

Table AI. 